\title{
INDKØBSLISTEN
}

\section{Kosmologi og klassifikationer i candomblé}

\author{
INGER SJØRSLEV
}

Indkøbslisten så sådan ud: en høne, en and, en blishøne, en anden slags høne, alt sammen til Iemanjá. Desuden en hane til Ogum, en høne til Liras ånd og en due til bori. Dertil en kylling til Exu og endnu en til renselsen, foruden hvide bønner, ris, mel, majs, grønsager, hvide melkugler, æg, hvidt, sort og rødt stof, stearinlys, kul, sytråd, brændevin, cigarer og kolanødder.

Det var en af de mange gange, der skulle arrangeres et offer, en obrigação, under ritualmåneden i det candombléhus i den brasilianske delstat Bahia, jeg er vendt tilbage til mange gange siden mit første feltarbejde i 1980. Efterhånden kender jeg arbejdsgangen og opskrifterne på, hvad der skal til, når der skal ofres til guderne. Alligevel var det nødvendigt at få det repeteret, når der var gået nogle år imellem mine besøg. Derfor fik jeg en indkøbsliste med på markedet.

Iemanjá, Ogum og Exu er orixaer. De tilhører klassen af ånder i den afrikanske gudeverden, folk i candomblé lever med. Lira er navnet på husets grundlægger og mangeårige overhoved, en højt respekteret mãe-de-santo, der døde i 1997 og nu er overgået til klassen af egun, ånder af afdøde. Ingredienserne til et offer er, som det fremgår, fra dyreriget, planteriget og mineralriget. Der er forarbejdede ting og „naturlige“ ting - dyr, altså både kultur og natur, hvis man tænker dualistisk. Men det er ikke hensigtsmæssigt at tænke dualistisk i denne sammenhæng, ligesom dyreriget, planteriget og mineralriget ikke er klassifikationer, folk i candomblé opererer med. Det kræver en anden slags klassifikation, hvis man skal have fat i candomblés kosmologi.

Her kunne jeg i stedet for have sagt candomblés ontologi og undladt at kommentere det nærmere, for det filosofiske begreb ontologi er for længst gledet ind i den antropologiske fagdiskurs, hvor det har levet et ret uantastet liv, indtil det blev trukket frem og sat under skarpt lys, sådan som det skete i den danske debat om mangfoldige verdener i foråret 2011 og tidligere i den, der foregik i Manchester i 2008 under en overskrift, der spurgte, om ontologi blot er et andet ord for kultur 
(Venkatesan 2010). Hensigten er imidlertid netop at lade candomblés klassifikationer bidrage til diskussionen om, hvorvidt ontologi er et velvalgt begreb $i$ antropologien. Det skal straks indrømmes, at jeg ikke mener, ontologi bare er et andet ord for kultur. Men spørgsmålet er, hvorfor ikke? Hvad er gevinsten ved at tale om ontologi frem for kultur, og hvad kunne være problemerne?

At der er blevet sat lys på ontologibegrebet, er der flere grunde til. En af dem er, at det har vist sig nødvendigt at nytænke og genoplive nogle af de spørgsmål, der ellers er blevet stillet med kulturbegrebet som ramme. Samtidig og sideløbende med ontologibegrebets stigende popularitet har man haft den materielle vending og argumenterne for at „tænke gennem ting“ (Henare et al. 2007). Det er store spørgsmål, der er blevet rejst i hele denne nytænkning, hvilket også fremgår af debatten i dette nummer. Med etnografien fra candomblé vil jeg tage fat på et enkelt spørgsmål, som forekommer mig at være underbelyst, nemlig betydningen af klassifikationer og grupper af ting snarere end ting i sig selv og ting som begreber, sådan som der lægges op til det i Thinking Through Things (ibid.), og som det siden er uddybet af en af forfatterne (Holbraad 2011:12). Det hævdes af fortalerne for at bruge ontologibegrebet, at man i stedet for at betragte det, informanter siger om og gør med ting, som måder at reprcesentere på, skal vi se dem som måder at definere på. Denne bevægelse fra repræsentation til definition er en kerne i det ontologiske projekt, som jeg ser det, og den kan risikere at spærre for en forståelse af, hvordan der opereres i praksis med en kosmologi. ${ }^{1}$

Som afslutning vil jeg glide over i en bredere diskussion af, om ontologi er et velvalgt begreb, hvis man ønsker at fastholde det antropologiske humanistiske projekt som et kritisk projekt.

Ved at tale om ontologi frem for kultur fremhæver man det værendes essens frem for repræsentationen af det. Et eksempel, der har været brugt i ontologidebatten, er, at hvis man i en kultur - det kunne være hos nuerne, som de er studeret af Evans-Pritchard - hævder, at tvillinger er fugle, så er tvillinger fugle. Denne forestilling kan ikke reduceres til, at fugle er en metafor for, en repræsentation af eller et symbol for tvillinger (Holbraad i Venkatesan 2010:183f.). Virkeligheden hos nuerne er konstitueret gennem sine symboler og repræsentationer, og derfor er den i sin essens grundlæggende anderledes end i den virkelighed, hvor tvillinger - som hos os selv - ikke er symboliseret ved noget særligt, men forstås biologisk som søskende, der er født samtidig og har været fostre i samme livmoder.

Slægtskabet mellem materialitetsteori og det, der bliver betegnet som den ontologiske vending, ligger $i$ at komme bag om repræsentationerne. Nyere etnografi har vist, at det kan give store analytiske gevinster. Den efterhånden omfattende litteratur om fetichen (Pietz 1985, 1987, 1988; Ellen 1988; Spyer 1998; Manning \& Meneley 2008) har øget forståelsen for tingen som betydningsbærende i sig selv snarere end et tegn, der henviser til noget andet, for eksempel noget transcendent 
som en abstrakt guddom, sådan som kristne vestlige missionærer ellers havde forstået de materielle figurer, folk tilbad og ofrede til (Pietz 1985, 1987, 1988). Studier af den protestantiske kristendoms udformning i andre samfund end de vestlige har vist, at tegn og skrift ikke altid kan forstås som noget, der viser hen til noget andet. Skriften, herunder den i Bibelen, må analytisk forstås som konkret materialitet, der virker i sig selv (Keane 1998, 2005; Engelke 2009). ${ }^{2}$ Kommunikerende og informerende tegn, der cirkulerer i offentligheder og modoffentligheder i den globale modernitet, er blevet analyseret i deres materialitet, det vil sige som størrelser i sig selv snarere end henvisende til noget andet (Gaonkar \& Povinelli 2003), og der er meget mere inspiration at hente her, for eksempel til forståelse af politiske protestformer (Sjørslev 2012). Sådanne eksempler viser, at indsigterne $i$ tegnenes materialitet og tegnene som andet og mere end henvisende har meget for sig, og den vending, der er sket med opmærksomheden på materialitet og form, vil uden tvivl blive ved med at være en stærk inspiration for tidens antropologi.

Ikke desto mindre er der en risiko for at overse andre vigtige forhold, når den analytiske vægt lægges på at tænke gennem ting og nå bag om repræsentationerne. Det er dem, jeg med baggrund i etnografien om candomblé vil forsøge at sætte lys på. Mit argument skal være, at ontologibegrebets popularitet og orienteringen mod ting tilsammen rummer en risiko for, at man glemmer tingenes orden, eller med old school-begreber, den betydning af klassifikation og kategorier, der ligger i en kosmologi. ${ }^{3}$ Ved bestræbelserne på at nå bag om repræsentationerne og se tegn i deres materialitet ligger der yderligere en fare for, at man afskærer sig fra at se, hvordan der kan manipuleres med tingenes og tankernes orden i konkrete praksisser. Det bliver tydeligt i magi og ritualer, hvor virkningerne netop beror på, at distinktioner kan overskrides og manøvreres med, men det gælder også i bredere politiske og magtmæssige sammenhænge. Jeg vil altså argumentere for, at lige så vigtigt som det er at tænke gennem ting, er det at tænke gennem kategorier og klassifikatoriske ordener. Det betyder, at vejen bag om repræsentationerne som en vej til analytisk forståelse ikke må udelukke en mere præmaterialistisk opmærksomhed på tegnenes henvisningskarakter.

Den ontologiske vendings ambition om at lade teorier fødes af begreber i etnografien vil ikke forsvinde med en sådan opmærksomhed på tegnene. Tværtimod kan der argumenteres for, at ambitionen bør udstrækkes til ikke bare at lade begreber, men også hele kosmologier informere teorierne, og at disse ikke kan forstås uden indgående studier af klassifikatoriske systemer. Med klassifikationerne undgår man samtidig ikke et metaplan, som angår grundlæggende epistemologiske forståelser af verden på tværs af eventuelle multiple ontologier. Et parallelt synspunkt er da også blevet fremført i en loyal kritik af den ontologiske vending. Der er blevet argumenteret for, at den ontologiske 
tænkning i antropologien rummer sin egen metaontologi og dermed paradoksalt går imod sine egne hensigter i retning af at tage det radikalt anderledes alvorligt som andet og mere end repræsentationer, epistemologier eller verdenssystemer. Denne metaontologi rummer en overordnet antagelse om det eksisterende, nemlig som noget, der dækker alt, både det, der er, og det, der er muligt. Når ontologi afløser kultur, bliver der lagt en sådan metaontologi ned over andre tænkemåder, og herved opstår paradokset (Heywood 2012:143, 148f.).

\section{Materialitetens orden}

Indkøbslisten til ofret i candomblé viser, at der klassificeres. Til bestemte guder hører der bestemte ting. Visse ingredienser, der hører hjemme inden for denne eller hin kategori, indgår i det samlede billede af, hvad der skal til for at få guderne i tale og opnå virkninger for de mennesker, guderne er knyttet til. Tingene er ikke bare enkeltstående ting; de er elementer, der indgår i et klassifikatorisk system af virkningsstørrelser. Eller med andre ord en orden. Det er en vigtig pointe i sig selv. Men i candomblés ritualer er pointen tillige, at det er en orden, der kan manipuleres. Den er ikke statisk, men bevægelig, og det er netop bevægeligheden hen over distinktionerne mellem den ene og den anden „slags“ $\mathrm{i}$ ordenen, der frembringer virkninger. Renselse, beskyttelse, styrkelse af et menneskes axé, dets kraft og styrke og udstråling, og appel til guderne om hjælp til fremgang i livet gennem ofre, det sker alt sammen ved at manøvrere tingenes orden på nogle måder, der viser ordenens bevægelighed, men som ikke kan analyseres, uden at man tager den mere stabile klassifikatoriske orden, der er udgangspunktet for denne manøvrering, med i betragtning.

Som det fremgår af indkøbslisten, arbejder man i candomblé med forskellige klasser af materialitet. Når der ofres, når der udøves magi, og når nogen bliver indviet til medium for en gud, opereres der med substanser og ting i forskellige former for orden som baggrund for de rituelle og transformative processer. Hvis der skal udføres et offer til guden Ogum, skal der arbejdes med forskellige ingredienser, som kan oversættes til den velkendte klassifikation i dyreriget, planteriget og mineralriget, men som i candomblés eget klassifikationssystem forstås som integrerede, essentielle dele af det, der er guden Ogum. Det er ikke de samme ingredienser som dem, der hører til en anden af guderne, for eksempel Iemanjá, der, som folk i candomblé siger, spiser nogle andre ting. Ogum spiser fjerkræ af hankøn, bønner af en særlig slags og i en speciel tilberedning, ristet yams og maniokmel, ligesom han hersker over nogle særlige urter. Når der ofres til Ogum, ordnes en del af disse ingredienser i fade og skåle på altre og offersteder sammen med materielle attributter, der passer til gudens egenskaber. Hos Ogum er de 
knyttet til hans rolle som erobrer, kriger, beskytter og den, der arbejder med jern, mekanik og teknologi. Hos andre guder er der andre elementer i spil.

Guderne er bevægelige. Deres bevægelighed viser sig igennem menneskers agens via manøvreringer inden for de kategorier af spiselige og materielle ting, der er en del af gudens essens, men også gennem bearbejdning af kategoriale forskelle, herunder forskelle på levende og dødt, mennesker og ting, dyr og guder og guder og mennesker.

Nøglebegreber i candomblé er axé, kraft, og at fazer santo, at blive indviet til medium for en orixa, en gud. Bori er en form for indvielse gennem et offer, et ebó, og otá er en sten, der er det materielle symbol for en relation til en gud. Alle er begreber og materielle tegn, der bør indgå i en samlet analyse af candomblé. Hvis man tog dem hver for sig, valgt ud som centralt begreb a la mana - hvilket axébegrebet kunne lægge fint op til, og hvilket også ligner det, Holbraad (2007) gør i sin elegante analyse af pulver og magt i den cubanske spådomspraksis ifa, som er beslægtet med candomblé - ville man ganske vist opnå at teoretisere på grundlag af et indfødt begreb, sådan som der advokeres for i Thinking Through Things. Men derved ville man samtidig miste noget. Disse forskellige begreber hænger nemlig tæt sammen i et system af kulturelle forestillinger og praksisser, en klassifikatorisk orden, som er bevægelig, men hvis bevægelighed ikke kan identificeres uden at kende de klassifikationer, der er baggrund for den.

I ritualerne opereres der med nogle grundkategorier af levende og dødt stof. Hvis der ikke blev arbejdet både begrebsmæssigt og i praksis med en afgørende forskel mellem disse to klasser af materialitet - levende og dødt - var der ikke nogen grund til at gøre sig al den ulejlighed med at ofre for ved den enes død, så at sige, at skaffe den andens brød. Når halsen skæres over på et offerdyr, er det netop forvandlingen fra levende til dødt, der i en samtidig bevægelse ,,vækker“en død eller midlertidigt slumrende ting til live. Konkret sker det ved at den sten, ota, som gennem indvielsen af et medium til en bestemt orixa er blevet tæt forbundet med dette medium, overhældes med blod fra offerdyret og derved bliver givet liv og styrket kraft: axé. I symbolsk forstand repræsenterer stenen mediets hoved, i ontologisk forstand er den mediet. Denne bevægelse kunne muligvis analyseres med axé som nøglebegreb eller tingen, otá, som den analytisk strømførende genstand. Men hele den rituelle praksis, der omgiver manøvreringen med tingene, hviler på grundkategorier af levende og dødt, suppleret med klasser af ting, der hører til guderne. Hvis den otá, der ligger i et fad og overhældes med offerblod, er mediet for gudinden Iemanjá, er den i offerøjeblikket samtidig gudinden selv, og hele pointen er, at den skifter karakter og substans gennem processen. Når offerritualet er slut, og gudinden har ,spist“ den mad, der er givet til hende, lægges stenen på plads i sin krukke med låg, hvor den hviler i en anden tilstand, indtil næste gang der skal ofres. 
En lille anekdote kan illustrere pointen med skiftet i tingens karakter. Som antropolog var det ikke muligt at arbejde i candomblé uden at deltage, hvilket indebar, at jeg måtte lade mig indvie for at kunne være med, om end jeg forblev en temmelig passiv deltager og mere en observatør i ritualerne. Men jeg havde og har min otá, min sten (nu burde jeg så rent ontologisk sige, at jeg er min sten). En af de mange gange, jeg skulle forlade mine venner i candomblé og rejse hjem, mente Mãe Lira, som havde indviet mig, at det nok var bedst, jeg fik stenen med. Man vidste aldrig, om jeg ville komme igen. Mest af alt bekymrede hun sig om, at hun selv snart skulle dø og ikke vidste, hvad der så ville blive af hendes candombléhus. I sin omsorg for sine rituelle døtre, herunder antropologen, gjorde hun derfor stenen klar, så jeg kunne tage den med. Det indebar forskellige ritualer, som gjorde, at jeg, som hun sagde, kunne rejse med den „tør“. Den skulle ligge i et kar med låg, og jeg fik købt sådan et lille kar, som hun godkendte, men i karret var der hverken blod eller honning, som ellers er noget, min gudinde spiser. Stenen lå med andre ord i karret og var tør. Da jeg nåede hjem med den, fik den honning, men intet blod. Det gik nok, var vi blevet enige om. Selvom det ikke blev særligt uddybet, hvad „tør“ betød, var der ingen tvivl om, at det var stenen i en anden tilstand, omklassificeret fra levende til relativt „død“, der var tale om. Og da jeg siden kom tilbage til candombléhuset med den igen, kunne den klassificeres tilbage fra tør til levende gennem et offer.

Ofrets teknologi kan ikke indfanges ved kun at tænke gennem ting. Der må tænkes gennem kategorier af ting, og kategorier er hverken enten materielle eller begrebslige. Som ordningsprincipper er de begge dele. Samtidig kan tingene skifte karakter over tid og igennem rituelle og sociale processer, så de går fra dødt til levende og tilbage igen. Hvis man vil tænke gennem de andres ting og begreber, må man også tænke gennem de andres ordningsprincipper og kategoriale forskelle. Med andre ord, det er ikke nok at tænke gennem ting, der må også tænkes gennem forskelle.

Lidt flere etnografiske detaljer kan illustrere denne pointe. I candomblé som i mange andre religioner er ritualet vejen til den kosmologiske verden. De vigtigste ritualer i candomblé er besættelsesritualet og offerritualet. Begge åbner en midlertidig vej ind $i$ en verden af guder og mytiske kræfter. I besættelsesritualet kaldes guderne frem ved hjælp af sang og særlige rytmer, som spilles på tre trommer - trommer, der er indviede, ved at der er blevet ofret til dem. Derved er de blevet omklassificeret fra verdslige musikinstrumenter til hellige og i en vis forstand levende ting, idet trommerne også har „spist“ et offer. Guderne, orixaerne, besætter de dansende, for hvem der under ritualet sker et kvalitativt skift fra menneskelige medier til guder. Det markeres kropsligt ved særlige bevægelser og bevidsthedsmæssigt ved, at mediet mister opmærksomheden på, hvad der foregår 
omkring hende eller ham. Som oftest har mediet, som kaldes datter eller søn af guden, filha-de-santo eller filho-de-santo, lukkede eller halvt lukkede øjne og må føres frem af andre og sættes i gang til den særlige dans foran trommerne, der er karakteristisk for guden. I den moderne candomblé understreges transformationen fra menneskeligt medium til gud ved spektakulære kostumer og diverse udstyr, som guderne iføres og får lagt i hænderne af deres hjælpere. Når dansen er slut, og ritualet går over i en anden fase, sendes guden bort. Den suspenderes, som det hedder, af rituelle hjælpere, og mediet er derefter tilbage i sin sædvanlige tilstand, om end træt, afslappet og lidt konfus. Omklassificeringen fra menneske til gud og tilbage igen er altså tydeligt markeret ved krop, ting, praksis og selvoplevelse, og denne rituelle omklassificering er hele ritualets kerne.

I offerritualerne er transformationerne hen over klassifikatoriske områder endnu mere tydelige. Omdrejningspunktet for ritualet er de mikrosekunder, hvor et dyr, oftest et stykke fjerkræ, lader livet. Ved sit blod, som hældes direkte fra dyrets krop ned over den sten (otá), der er (ikke symboliserer, men i disse afgørende minutter er) den, der er indviet til guden, giver dyret liv - axé - til mennesket, der ofrer, og som i disse afgørende øjeblikke er dybt forbundet med guden. Det er, som allerede nævnt, det radikale skift mellem levende og dødt og tilbage igen, der giver axé. Candombléfolket kalder det at fazer obrigação, at gøre et offer eller i bogstavelig oversættelse opfylde en forpligtelse (Sjørslev 2007:192-4). Det er helt afgørende, at det dyr, der lader livet, hører til den rette slags, der passer til guden. Til de kvindelige guder ofres der fjerkræ af forskellig slags, altid af hunkøn, til de mandlige fjerkræ af hankøn. Når der ofres geder, skal kønnet også passe, og til hele det omfattende offerritual, som rummer mange flere detaljer, end jeg kan få med her, hører også den mad, der spises bagefter. Her er det helt afgørende, at den, der har ofret, kun spiser nogle bestemte ting i overensstemmelse med den gud, der er ofret til. Andet er tabuiseret. Af de ingredienser, der var på min indkøbsliste, var duen bestemt til det livgivende offer, bori, der knytter en indviet nærmere til sin orixa. Her bør det være en due, der ofres, aldrig for eksempel en høne. Det føles næsten som et overgreb bare at skrive det, hvilket vel vidner om, at man får integreret candomblés konceptuelle klassifikationer, når man i et eller andet omfang deltager i dens praksis.

Resten af den højst blandede sammensætning af ingredienser på indkøbslisten hørte til tricksterfiguren, sendebuds- og fortolkerguden Exu, i sig selv en overordentlig sammensat skikkelse, som er med i alle ritualer og den, der bringer ofre fra denne verden til gudernes. På samme tid som han er den, der renser, er han også til konstant fare for at bringe uro i den kosmiske orden. Derfor begynder ethvert offer med et offer til Exu, og sammensætningen af ingredienser kan tages som udtryk for denne skikkelses sammensatte karakter. Der er klare lighedsaspekter 
i det, a la den ene af de to klassiske magiske former ligheds- og berøringsmagi (Frazer 1996 [1922]), når disse ingredienser fra at være smukt ordnede i fade og efter at have været en tur ned ad kroppen på den, der skal renses, ender i en rodet bunke på gulvet for derefter at blive båret ud og bragt et godt stykke væk, hvor den rodede masse som affald forventes at gå i opløsning og indgå i et kosmisk kredsløb (Sjørslev 2006).

I disse vigtige ritualer som i andre mindre, der går ud på at rense og beskytte og sommetider at øve negativ indflydelse på andre, spiller forskelle en afgørende rolle. Der kan ganske vist identificeres noget lighedsmagi, og en del af det, der foregår, kan, som det skal vise sig i næste afsnit, tænkes i mere participatoriske termer, men manøvreringen af klassifikatoriske forskelle er eklatant. Hvad enten det drejer sig om at etablere forbindelse til det kosmiske eller operere med jordiske sociale kræfter, arbejdes der ud fra en materiel orden, der er skabt gennem klassifikatoriske forskelle.

Denne orden er bærende for candomblés kosmologi. Her er det en pointe, at jeg omtaler den som candomblés kosmologi og ikke ontologi. Med kosmologibegrebet ønsker jeg nemlig at understrege, at den kosmiske orden fremkommer gennem klassifikationer af ting og mennesker i forhold til guder, og at det samtidig er denne orden, der kan manipuleres og opereres med i ritualer og magiske arbejder. Det forhold, mener jeg, ville det være sværere at få frem, hvis jeg kaldte det for candomblés ontologi. Men at spørgsmålet om ontologi kan gribes an på en anden måde, viser den brasilianske antropolog Marcio Goldmans arbejde.

\section{Candomblé i ontologisk forståelse}

Goldman har beskæftiget sig med det, han kalder candomblés ontologi, med udstrakt brug af de filosofiske tanker og begreber, der kan siges at høre sammen med den ontologiske vending i antropologien, herunder ikke mindst indflydelsen fra den franske filosof Gilles Deleuze og hans medforfatter til storværket Tusind plateauer (2005), Félix Guattari. Jeg vil gå lidt ind i Goldmans analyse af candomblés ontologi for derefter at diskutere den ud fra mine præmisser om betydningen af klassifikation og kosmologisk orden. Goldman studerede en variant af candomblé, der er en smule anderledes end den, jeg selv har arbejdet med, men de små forskelle er ikke af betydning for det overordnede argument i denne sammenhæng. ${ }^{4}$

Ifølge Goldman kan candomblés ontologi opsamles som en slags monisme, der hævder eksistensen af en enkelt kraft. Det er denne kraft, der kaldes axé, og den ligner andre mere velkendte antropologiske begreber såsom mana. Modulationer af axé er det, der udgør alting i eksistensen, og det, der potentielt kan eksistere i 
universet. Disse modulationer sker gennem konkretiserings-, diversifikations- og individualiseringsprocesser. Guderne, orixaerne selv, er ikke andet end en manifestation af en specifik modulation af axé. De multiple væsener og ting i verden - sten, planter, dyr og mennesker, men også farver, lugte, dage og år - hører til orixaerne i den forstand, at alt har del i denne kraft, som på samme tid er generel og individualiseret. I en vis forstand er ethvert væsen ikke andet end en slags krystallisering, der er resultatet af det modulerende flow af axé, som begynder som en generel og homogen kraft, men kontinuerligt bliver mere og mere diversificeret og konkret (Goldman 2007:110). Det er en kompleks kosmologi, der på denne måde kommer til udtryk i forståelsen af kraft og kræfter i candomblé. Den ville kræve flere detaljer, end der er plads til her, for at komme til at stå helt klart for læseren, men i denne sammenhæng må det være tilstrækkeligt at understrege Goldmans syn på candomblé som en særlig og radikalt anderledes, ikke bare kosmologi, men ontologi. Den viser sig tydeligt i opfattelsen af, hvad en person er, og hvordan en person bliver til.

Mennesker er delt op mellem orixaerne. Candomblé rummer en opfattelse af personhood, en antropologi kalder Goldman det, altså en indfødt forestilling om, hvad mennesket er for en størrelse i den filosofiske betydning af ordet antropologi. Mennesket antages at være multipelt og sat sammen af „lag“ af forskellige materielle og immaterielle elementer, herunder den orixa, et menneske hører til, hvis „søn“ eller „datter“ det er, og dertil ofte andre orixaer med en sekundær status. Det kan for eksempel være en ånd eller beskytter, man har arvet fra en af sine forældre. Dertil kan man have en mere generaliseret forfaderånd, en skytsengel, en sjæl, og der kan være flere endnu. Pointen er, at en person ikke er født som en færdiglavet størrelse, men bliver komponeret over tid, herunder gennem den indvielse til orixaen, som er det helt centrale i candomblé.

Indvielsesprocessen kaldes altså ,at skabe hovedet", fazer a cabeça. Hovedet skabes i samme omgang, som orixaen skabes, og initiation kan også kaldes at skabe ånden (orixaen). Det er på den måde ikke bare mennesket, der er en over tid skabt skabning, det er også ånden eller guden. ${ }^{5}$ Denne konstruktivisme kan ved første øjekast synes at være ude af trit med den ontologiske præmis, siger Goldman selv, men det er den alligevel ikke, for orixaen er ikke så meget en individualitet som et resultat af „the cutting of a flow“, et snit, der kan lægges i forskellige niveauer. Candomblés ritual producerer på den måde to individualiserede entiteter. Dels en struktureret person ud af et mere eller mindre udifferentieret individ og dels - ud af en generisk orixa - en, der aktualiseres som en individuel ånd, en persons specifikke gud med helt specifikke navne inden for en af de overordnede guder som Iansa, Ogum, Iemanjá eller en af de andre i den lille snes guder, der er de mest almindelige i den brasilianske candomblé. Disse individuelle orixaer 
får altså deres egne navne og karakteristika, på samme måde som folk bliver genfødt og transformerede gennem indvielsen. Både personen og orixaen bliver skabt, og det er i trancen, mens mediet er besat af guden, at de to sider af dette skabte konvergerer. De bliver et og det samme. De forskellige komponenter i et menneskeligt væsen forenes i en ligevægt og hæver mennesket op i en næsten guddommelig status (op.cit.112).

Til forståelse af denne proces bringer Goldman begrebet tilblivelse, i Deleuze og Guattaris forståelse af det, ind i billedet. ${ }^{6}$ Tilblivelse er et kompliceret begreb, der samler meget af Deleuzes filosofi, og som det ville kræve en hel del mere udfoldelse, end der er plads til her, at yde retfærdighed. I nærværende sammenhæng er det tilstrækkeligt at fremhæve, at det står for forskel som det, hvor ud af identiteter kan forstås som singulariteter i tid. Begrebet rummer en kritik af den filosofi, der søger at grunde sig i væren og identitet som stabile former (May 2003). Tilblivelse står ikke for enshed, heller ikke for efterligning, det er en komposition af begge dele og som sådan et abstrakt begreb, der indebærer både samme substans og efterligning. ${ }^{7}$

Tilblivelse er altså en komposition. Men hvad betyder det for forståelsen af candomblé? Tilblivelse er bevægelse, bevægelse ud fra den form, man har, fra det subjekt, man er, fra de organer, man består af, eller fra de funktioner, man udfører. Tilblivelse er en proces, siger de to psykoanalytisk orienterede forfattere Deleuze og Guattari. Overført til candomblé passer det godt på den måde, at relationerne mellem guder og mennesker kan tænkes som en form for bevægelse, hvorigennem et subjekt forlader sine egne væsensbetingelser, nemlig det at være menneske, ved hjælp af affektrelationer, der er etableret med en anden væsensbetingelse, nemlig det at være en gud. Affekt skal forstås som det at give navn til noget, der berører, forandrer eller modificerer en tilblivelse i betydningen at blive et andet væsen som for eksempel et dyr. At blive til et dyr - det kan være en hest - betyder ikke, at mennesket $\mathrm{i}$ egentlig forstand bliver til en hest eller psykologisk identificerer sig med dette dyr. Det indebærer derimod en følelse af, at „hvad der sker hesten, kan ske mig“.8

På samme måde skal gudetilblivelse forstås i Goldmans udlægning af candomblés ontologi. Nøgleordene er bevægelighed og fraværet af en substantiel identitet. Det passer godt med candomblés forståelse af personer, der bliver mere og mere „sig“ $i$ en bevægelse af samtidighed med en stærkere og stærkere relation til guden. Der er ikke noget forudgivent substantielt selv, men en proces, hvori menneske og gud bliver til i en samtidig bevægelse.

Meget i Goldmans analyse virker overbevisende i forhold til min egen etnografi, og Deleuze og Guattaris filosofiske begreber er på mange måder velvalgte til udlægning af candomblés ontologi på den måde, Goldman gør det. Alligevel kan jeg ikke komme væk fra indkøbslistens betydning og den lille kritiske stemme, 
den rejser, over for Goldmans ellers på mange måder besnærende udlægning. Det er ikke så meget det, at tingene til offerritualet skulle købes ind. Det er den implicitte orden, der ligger i listen. Hvorfor lige de ting til de guder? Hvilken rolle spiller de klassifikationer, der ligger bag, og hvilken betydning ligger der i at have en orden, og kan den indfanges alene med begreber som bevægelighed og tilblivelse?

Hvis man skal være tro mod en anden side af candomblés praksis end den, der fremkommer gennem analysen af relationen til en gud og indvielsesprocessens betydning for, hvordan personer konstitueres, kommer man ikke uden om at se nærmere på klassifikationernes betydning og de forskellige manøvreringer med og på tværs af kategoriale forskelle. Klassifikationerne er hele tiden i spil, både verbalt og i den tavse udøvelse af ritualerne. Hvilken betydning har de tabuer, der er omkring en forkert sammensætning af ting? Hvorfor er det ikke lige meget, om det bliver en hane eller en høne, hvorfor er det kun gudinden Iemanjá, der spiser en særlig slags høns fra Angola? Hvorfor hører farverne lyseblå og hvid til Iemanjá, mens rød hører til gudinden Iansa? Hvad betyder denne tingenes orden, og hvordan virker den bevægelighed, der er i den?

For candombléfolket selv er der ingen tvivl om, at klassifikationerne spiller en stor rolle. Farver, smykker, mad og offeringredienser er alt sammen noget, der tales om med selvfølgelighed, som når man hører udtrykket meu orixa veste azul - „min orixa klæ'r sig i blåt“. Eller når man ved synet af en særlig perle siger: Ela é dela, „den hører til hende“, eller mere præcist, „,en er af hende“, hvilket sidste peger mod noget af samme (tilblivende) væsen og dermed kan understøtte Goldmans ontologiske forståelse. Min pointe er da heller ikke, at ting ikke opleves som dele af guderne eller deres mennesker, men at det ikke er en hvilken som helst ting, der kan være del af hvem som helst. Der er forskelle, og der er orden. Og klassifikationerne af, hvilke ting der hører til hvilke guder, er forudsætningen for de rituelle arbejder som ofre og andre, hvor hele materialiteten manøvreres på baggrund af den klassifikatoriske, kosmologiske orden. Manøvreringen består både i bekræftelser af, hvad der hører sammen og er del af hinanden, og i overskridelser. ${ }^{9}$

Det kan illustreres ved at gå vejen omkring et klassisk begreb i antropologien, nemlig begrebet participation, som kommer fra den franske antropolog LévyBruhl. Participation dækker særlige relationer af symbolsk og mystisk karakter, som Lévy-Bruhl mente, mennesker i primitive samfund havde til ting i deres omverden. Goldman er siden gået dybere ind i Lévy-Bruhls univers og har vist, hvordan den variant af candomblé, han har studeret, i sin praksis følger loven om participation (Goldman 1994, 2009). Lévy-Bruhl så denne lov som kernen i det, han kaldte den primitive mentalitet og omtalte som prælogisk tænkning (Lévy-Bruhl 2010). Hans inspiration kom fra den etnografiske viden - som han 
havde læst sig til, den var ikke indhentet af ham selv - om indianske folk i det brasilianske Amazonas, der så sig selv som papegøjer. Det var spørgsmålet om på samme tid at være sig selv og noget andet end sig selv, der gav anledning til undren. I Goldmans analyse forbindes Lévy-Bruhls tanker med de aktuelle filosofiske trends, hvor Deleuze er den store inspirator, og det er gennem begrebet participation, han når frem til, at man i candomblé på samme tid kan være både sig selv og noget andet, såsom en gud.

Mit ærinde her er ikke at fornægte betydningen og relevansen af Goldmans analyse. Jeg mener tværtimod, at den siger noget overordentlig væsentligt og rigtigt om personopfattelsen og forståelsen af ting i candomblé - og at den dermed meget vel kan siges at afdække en anderledes ontologi for os. Ikke desto mindre vil jeg holde fast ved min argumentation for, at candomblés praksis må tage klassifikationer og manøvreringen hen over kategoriske forskelle med i betragtning, og at ontologi dermed bliver et ikke helt velvalgt begreb, fordi ontologi konnoterer essentiel og vedvarende væren, mens jeg understreger, at candomblés praksis indebærer en høj grad af manipulation og manøvrering, som indebærer skiftende værensformer. Den ene position udelukker dog ikke nødvendigvis den anden. Den franske antropolog Roger Bastide, der er ophavsmanden til de mest omfattende klassiske studier af candomblé, gør netop opmærksom på, at participation ikke kan forstås uden om praksis (Bastide 1978:273), og den praksis, jeg fremhæver, er altså en, der indebærer rituelt arbejde med manøvrering mellem forskellige klasser og hen over grundkategoriseringerne i levende og dødt, mennesker og dyr og mennesker og guder, hvilket gør det vanskeligere at identificere en ontologi i den klassiske forståelse af dette begreb som grundlæggende værensmåder.

Der ligger en konceptuel ordning bag den praktiske manøvrering, og den kan ikke forstås uden om en anden forskel, nemlig forskellen mellem tingene og begreberne om dem. Praksis er grundet i en begrebsmæssig orden, en orden, som kan overskrides og dermed er bevægelig, men uden en vis stabilitet i denne orden kunne der ikke være nogen overskridelse. Bevægeligheden beror på, at der hersker en orden, som er den, der bærer kosmologien. En vis statik i kosmologiske, klassifikatoriske systemer er altså forudsætningen for bevægelighed. På samme måde er tegn i form af materielle repræsentationer, som indkøbslistens ingredienser for gudernes egenskaber, og immaterielle, som gudernes navne, forudsætningen for, at der kan skabes personer og guder i løbende processer, sådan som Goldman beskriver det. Hvis tegn og begreb betragtes som værende hinanden i et tidløst ontologisk perspektiv, kan der ikke forekomme en proces af vækst, af mere eller mindre, eller som i candomblé en bevægelig tilbliven af person og gud. Klassifikatoriske forskelle er en forudsætning for tilbliven. 


\section{At tænke gennem kategorier: diskussion og konklusion}

I candomblés praksis er begrebsmæssige kategoriseringer og praktisk handling uadskillelige. De praktiske handlinger forudsætter en differentiering i ting af forskellig slags. Rituelle ofre, magiske handlinger og indvielsen af medier til guderne er alt sammen arbejde, der ikke kan finde sted uden en begrebsmæssig manøvrering med materielle kategorier og klassifikationer af mad, dyr, farver og ting i relation til de guder, der er i spil. Det er det, indkøbslisten viser. Den, der er indviet, er feita, skabt over tid, som Goldman siger, men feita betegner både en proces og en orden, en orden, der også adskiller dem, der er indviede, fra dem, der ikke er. Da jeg selv af candombléfolket regnes for at være indviet $i$ et vist omfang, måtte jeg udstyres med indkøbslisten som en repræsentant for den lille flig af en mere omfattende kosmologisk orden, som mit offer skulle foregå inden for.

Fra candomblés etnografi hentede jeg således argumentet, at det er nødvendigt at lære kategoriseringerne at kende og for at forstå candomblé at tænke gennem disse kategorier. At tænke gennem ting, det vil sige de andres begreber, kan ikke gøres uden også at tænke gennem den måde, disse begreber er organiseret på i en praksis og en klassifikatorisk orden.

Mit ærinde med at fremføre nødvendigheden af også at tænke i kategorier har altså sin etnografiske grund i ovenstående veje ind i candomblés verden. Men det var også det mere generelle spørgsmål om, hvorvidt ontologi er et velvalgt begreb for antropologien, der satte tankerne i gang. Thinking Through Things er bogen, der taler for at tage de andres ontologi alvorligt, så vi holder op med at tale om forskellige kulturelle fortolkninger af verden for i stedet at søge indblik i verdener, som de er - essentielt, det vil sige ontologisk, er. I introduktionen til bogen kalder de tre forfattere deres indgang til tingene for radikalt essentialistisk, men de siger også, at de er radikalt konstruktivistiske og gør det med henvisning til Deleuze og hans forståelse af sammenhængen mellem begreb og ting (Henare et al. 2007:13). Det er altså muligt at være essentialist og konstruktivist på samme tid, og det er her, ontologien kommer ind.

Ontologi indebærer i en vis metafysisk filosofisk forståelse (som dog ikke er den eneste), det fuldstændige sammenfald mellem tegn og ting, hvor det værende falder sammen med sproget. En sådan forståelse af ontologi efterlader, vil jeg mene, nogle problemer og risici. ${ }^{10}$ Den ontologiske orientering, som jeg ser som sammenhængende med den materialitetsorienterede teoretiske bestræbelse på at komme bag om repræsentationerne, rummer en fare for at overse betydningen af de forskelle, der kun kan identificeres gennem differentieringen i ting og begreb. ${ }^{11}$

De, der taler for ontologibegrebet, gør det blandt andet med det argument, at det er antropologiens opgave at generere begreber. De vil hævde, at den 
ontologiske tilgang tager det, man møder i felten, alvorligt uden at forsøge at bortforklare det $\mathrm{i}$ sine bestræbelser på at foretage det, der i gamle dage hed kulturelt oversættelsesarbejde. Der er altså både en politisk og en metodisk dimension i de ontologiske bestræbelser. Opmærksomheden på mangfoldige ontologier kan metodisk-teoretisk set generere nye begreber og bringe os ud over vor egen ontologi. Den brasilianske antropolog Viveiros de Castro har sagt, at ontologisproget er vigtigt af én specifik taktisk grund, nemlig at modvirke en tendens til at se indfødte folks tænkning som fantasi og uvirkelighed og reducere den til en vidensform i stedet for at tage den for reel viden på linje med den vestlige videnskabs viden. Han taler ligefrem om, at der i verden bør herske, hvad han kalder ontologisk selvbestemmelse (Viveiros de Castro 2003:18). Det er alt sammen gode argumenter for at have taget et begreb frem, der kan genopvække opmærksomheden på det radikalt anderledes og mane til forsigtighed over for at tæmme den og de andres verdener for hurtigt ind $i$ en velkendt analytisk skabelon i sine bestræbelser på at udføre det antropologiske oversættelsesarbejde. Men også her bør der manes til besindelse.

I én filosofisk betydning af ontologi er der ikke nogen forskel mellem ordene og det, der er. Sproget vil i en sådan utopisk ontologisk perfekt verden være det fuldkomne udtryk for verden, som den er. Der vil ikke være forvirring og usikkerhed. Der vil ikke være snyd og løgn og leg og driven gæk med ordene. Der vil ikke være nogen tvivl, ingen flertydige fortolkninger, ingen misforhold mellem tegnene og det, de henviser til, ingen kreative misforståelser, ingen distortion, ingen forvrængninger, ingen utilsigtede bivirkninger af handlinger med bestemte hensigter. Ingen forskelle. Denne forståelse af ontologi er, indrømmet, en filosofisk abstraktion, men konnotationerne til en sådan forståelse, vil jeg mene, ligger i ontologibegrebet, og de kan risikere at blive understøttet af den materialitetsteoretiske interesse for sammenfaldet af tegn og begreb. Det er en af grundene til, at der bør udvises en vis forsigtighed over for brugen af ontologibegrebet.

Sammenfattende må man derfor spørge, om ontologi, hvis der med begrebet følger konnotationer som de ovenfor nævnte, er et velvalgt begreb. Er det tillige ikke ironisk at vælge et begreb med så megen tyngde af traditionelt europæisk filosofisk tankegods, en hel metaontologi, når man ønsker at tale for at teoretisere på grundlag af begreber, der er centrale for de andre, og ikke ens egne?

Et sidste aspekt af ontologidebatten kan formuleres som et spørgsmål om, hvorvidt ontologi er et velvalgt begreb, hvis man ønsker at fastholde det antropologiske projekt som et humanistisk kritisk projekt. Viveiros de Castro vil hævde, at det netop er det, han gør, når han taler om multinaturalisme, altså forskellige opfattelser ikke bare af kultur, men af natur, og om multiple ontologier og ontologisk selvbestemmelse. 
Man må give Viveiros de Castro og andre ret $\mathrm{i}$, at ontologi ikke bare er et andet ord for kultur, for ontologi vil netop understrege essentielle forskelligheder, som ikke bare ligger i forskellige repræsentationer af den samme verden (som kulturbegrebet hævdes at pege imod), men i væsensforskellige verdener af både kultur og natur. Verdener er forskellige, menneskers liv tager sig ikke bare forskelligt $u d$. Vi bebor verden forskelligt på en dyb måde, alt efter om vi sidder i offerværelset i Bahias candomblé eller på et kontor i København. Men samtidig må man indvende, at vi mennesker dog kan være i hinandens verdener, og vores anderledes verdener kan lappe over hinanden. De andres verdener er ikke radikalt anderledes på alle måder. Der er folk i Bahias candomblé, der lever i den samme slags verden som min i det daglige. Som Annemarie Mol (2005) viser med sit arbejde på et hospital i Holland, er multiple ontologier da heller ikke et spørgsmål om at befinde sig forskellige geografiske steder, det er et spørgsmål om, hvordan man er i samtidige, ontologisk forskellige verdener. I hendes europæiske medicinske studiefelt er det som patient, forsker eller behandler. Ontologier er altså ikke totalomfattende. Vi kan flytte ud og ind af dem. Forskeren kan også blive patient, ligesom antropologen kan flytte sig ud af offerværelsets rituelle slagtninger og ind $i$ en anden ontologi af for eksempel dyrevelfærd. Verdener tager sig ganske rigtigt ikke bare forskellige ud, vi er i dem på forskellige måder, men disse verdener binder os ikke på nogen total måde. Vi kan bevæge os ud og ind af dem, og vi kan heldigvis kommunikere hen over dem. At Mol alligevel har valgt at karakterisere de forskellige verdener som ontologisk forskellige, har givet megen ny indsigt, hvad den indflydelse, hendes arbejde har haft, vidner om. Men jeg synes alligevel ikke, det endeligt afgør diskussionen om, hvorvidt ontologi er et velvalgt begreb. Man kunne lige så vel argumentere omvendt på grundlag af et begreb som multiple ontologier og se det som dybt paradoksalt, når det hævdes, at sådanne kan være sameksisterende, og at de samme personer kan være i flere ontologier.

Alle gode og inspirerende indsigter til trods mener jeg ikke, ontologi er noget helt velvalgt begreb, når det gælder det antropologiske projekt som et humanistisk, kritisk projekt. Det, ontologibegrebet vinder i understregning af radikale anderledesheder, taber det, hvis det ikke forenes med en understregning af, at det ikke skal forstås som en totalitet. Det må ikke forstås som altomfattende for forskellige verdener uden gensidige overlap, delfællesskaber og sprækker.

Ontologi er ikke så skidt, at det bør forvises fra den antropologiske fagdiskurs, men det bør anvendes med stor varsomhed. For det rummer ikke bare faren for et totalitært syn på verden(er), som overser klassifikationer og ordningsprincipper, der spiller afgørende roller for etnografisk forståelse af kosmologi og praksis. Man risikerer også at overse hele det felt af manipulation, for ikke at sige løgn og svig 
og magtmisbrug, der findes i verden, og som ikke kan finde sted uden at operere med forskelle mellem det, der siges, og det, der gøres, mellem repræsentationer og det, de henviser til, mellem italesatte hensigter og faktiske handlinger. I dette felt, som også kan sammenfattes som et politisk felt, hører antropologiens humanistisk kritiske projekt også hjemme.

Hvis argumentet for en ontologisk tilgang til verdener frem for en kulturalistisk er, at det hermed ikke bliver et spørgsmål om at anvende analytiske begreber på etnografiske data, men snarere at tillade etnografiske data at virke som løftestænger for transformationer af analytiske begreber, må opgaven være at lokalisere vores begrebers utilstrækkeligheder for at komme frem til nogle bedre. Men behøver man virkelig et filosofisk begreb som ontologi til det? Og er det ikke en fattig løsning på et reelt problem - nemlig hvordan man undgår at fange fremmedhed og andre verdener i egne og for de andre fremmede begreber - at vælge et ord, som i den grad er undfanget i en europæisk, kernefilosofisk tradition? Her ligger der et stort paradoks i den ontologiske vendings argumenter.

Forskelle i verden kan, som ontologifortalerne siger, ganske rigtigt ikke reduceres til forskelle i repræsentationer. Når nuerne siger, at tvillinger er fugle, er tvillinger noget andet for dem end for folk, for hvem de er biologiske søskende født af den samme mor på samme tid. Men det må være en vigtig pointe, at vi stadigvæk kan tale med nuerne om sagen. Det gjorde Evans-Pritchard, og han skrev deres og sine egne refleksioner ned. De refleksioner, vil jeg hævde, kunne ikke have fundet sted uden det mellemrum, den forskel i sprogets konsistens, som gør, at vi mennesker kan flytte vores tanke så at sige. Ord og væren er ikke absolut sammenfaldende, og det er vel hele grundlaget for menneskelig refleksion. Jeg antyder det forsigtigt, amatørfilosof som jeg er, og det er de fleste andre antropologer i øvrigt også. Men jeg vil mene, at ontologi også af disse grunde ikke er noget helt godt ord. Det er nemlig ikke tilstrækkeligt til at omfatte den leg og manipulation med kategorier og klassifikationer, som er forudsætningen for en hel masse menneskelig aktivitet, fra ofre og magi til antropologiske analyser. Og det kan ligefrem risikere at føre til, at vi overser vigtige sider af den slags aktivitet. Hvad man skulle sætte i stedet, er straks sværere at se, for det går ikke i alle sammenhænge bare at gå tilbage til kultur. Der er brug for nye begreber. Lad os dog her tage „ontologisterne“ på ordet og prøve at finde begreberne hos dem, vi studerer, frem for at gå på rov i en nabodisciplin, der som filosofien sjældent indbyder til at rejse sig fra lænestolene for at gå ud i verden og finde ud af, hvorfor der hører forskellige høns til forskellige guder. 


\section{Noter}

1. For Holbraad er det et argument, at det i antropologisk analyse ikke drejer sig om at applicere analytiske begreber på etnografiske data, men snarere at lade etnografiske data virke som store løftestænger for transformationen af de analytiske begreber (Venkatesan 2010:180). I den forstand handler ontologiseringen om vilkårene for videnskabelig begrebsdannelse. Ontologi er resultatet af antropologens systematiske fors $ø \mathrm{~g}$ på at transformere andre folks begrebsmæssige repertoire, så man kan beskrive deres etnografiske materiale på en sådan måde, at det ikke er absurd. Og det, mener Holbraad, er forskelligt fra kultur. Kultur er et sæt repræsentationer produceret af de folk, vi studerer. Vi taler jo også om „deres“ kultur. Sådan er det ikke med ontologi. Ontologi er et sæt af antagelser, der er postuleret af antropologen med analytiske formål (ibid.). Med ontologibegrebet $i$ antropologien tager man ikke for givet, at den verden, der for os er, er den, der er for andre, og at de andres anderledesheder derfor kan forstås blot som andre repræsentationer af den samme verden - den, vi kender og ved, er den virkelige verden. Ontologitænkningen anerkender mangfoldige virkeligheder i verden. Den kræver, at de andres virkeligheder bliver taget alvorligt, ikke bortforklaret som fejltagelser eller „bare“ sjove eller mærkelige repræsentationer af den samme verden, som er velkendt i vor egen virkelighed. I den forståelse kan selvkritikken over for vestlige semiotiske ideologier og etnocentrisk filosofisk tænkning på grundlag af rodfæstede kartesianske og kantianske forestillinger kun hilses velkommen (jf. Candea i Venkatesan 2010). Men hvor der vindes ny indsigt, er der fare for at tabe gammel, som snarere end at afvises bør inkorporeres i et nyt og mere nuanceret billede. Min fortale for at tage klassifikation og kategorisering med ind i analysen - hvilket ikke kan gøres uden at tage repræsentationer alvorligt som repræsentationer i gammeldags forstand, det vil sige som henvisende snarere end materielle - skal forstås i det lys.

2. Se også Karen Lisa Salamons artikel om forståelse af skriften i den jødiske religion i Tidsskriftet Antropologi Ordentlige ting (Salamon 1990).

3. Grundlaget for klassifikation var et spørgsmål, der optog den klassiske antropologi. En afgørende indsigt i spørgsmålet blev gjort i 1903 af Durkheim og Mauss i deres lange artikel „Primitive Classification“ (1963). De forklarede klassifikationer af ting og forhold i naturen som noget, der havde rod i samfundet, og mente, at der klassificeres, fordi samfundet er ordnet i grupper. Det er ikke der, jeg vil hen med min understregning af klassifikationers betydning, men jeg indrømmer, at jeg ser den klassiske antropologis indsigter som relevante, uanset at der har fundet en modbevægelse sted i sociologien, videreført i Latours aktør- og netværksteori (Latour 2008) og med indflydelsen fra Deleuzes filosofi.

4. Goldman arbejdede med den „nation“ i candomblé - hvor de forskellige etniske varianter går under navnet nation (nação) - der hedder angola, mens mit candombléhus regner sig for ketu, dog med elementer fra angolavarianten.

5. I en mere klassisk sociologisk formulering vil man sige, at gudernes skabelse er afhængig af menneskets - en idé, der ligger dybt i de vestafrikanske yorubaers forestillinger om orixaerne (Barber 1981).

6. Tilblivelse er Deleuze og Guattaris danske oversætter Niels Lyngsøes valg for det franske devenir, som på engelsk er oversat ved becoming.

7. Interessant i forhold til min argumentation er det, at de to filosoffer fremkommer med deres begreb tilblivelse som et resultat af deres livtag med klassifikationssystemer.

8. Mit referat af Deleuze og Guattaris begreb tilblivelse er hovedsageligt foretaget på grundlag af Goldmans tekst. Det kan dog være nyttigt også at konsultere de relevante sider i originalteksten Tusind Plateauer (2005:297-304), hvor forfatterne diskuterer serialismen og strukturalismen i forhold til tilblivelse. Deres diskussion er også en diskussion af klassifikationsformer. Om serialismen og strukturalismen siger de, at de ,veksler mellem at graduere egenskaberne efter deres ligheder og ordne dem efter deres forskelle“ (op.cit.304). Strukturelle klassifikationer er ikke irrelevante for dem, men de mener, det er et falsk alternativ at sige, at enten efterligner 
man, eller også er man. Tilblivelse er det, der er virkeligt, ,ikke de angiveligt faste led, som den eller det, der bliver til, går igennem“ (op.cit.302). Hvor Goldman i sin analyse af tilblivelse i candomblé lægger vægten på det falske alternativ og tilblivelsen selv, går jeg et par skridt tilbage fra begrebet og argumenterer for, at ordningsformerne - hvad enten de er serielle eller strukturelle - ikke er uvæsentlige for tilblivelsens karakter.

9. At der manøvreres med forskelle på to ledder-både som mere-eller-mindre og som enten-eller - kan måske illustreres ved at bruge begreberne analog og digital. Overskridelserne er analoge, når der manøvreres med tingene som del af hinanden, og digitale, når levende bliver til dødt $\mathrm{i}$ ofret, og ofrets „døde“ genstand, som for eksempel stenen, ota, bliver givet liv.

10. I en anden filosofisk forstand vil der dog ikke være noget problem, for ontologibegrebet dækker ikke bare spørgsmål om, hvilke enheder der eksisterer, men også hvordan de er grupperede og relaterede i hierarkier og i forhold til ligheder og forskelle, kort sagt, hvordan der er en orden. På den måde er der ikke noget i vejen for, at man kan forblive på klassisk antropologisk grund med et tilbageblik til Durkheims og Mauss' analyser af de primitive klassifikationssystemer og stadigvæk tale om ontologi. Men at ontologi er et komplekst begreb fremgår, så snart man åbner et filosofisk opslagsværk. Jeg har hovedsageligt hentet min amatørviden om begrebet i dets forskellige betydninger fra Stanford Encyclopedia of Philosophy (http://plato.stanford.edu/ entries/logic-ontology/) og Theory and History of Ontology (http://www.ontology.co/ontologydefinitions-one.htm).

11. Verden er som allerede nævnt fuld af gode grunde til at interessere sig for materielle tegn og anfægte en klassisk saussuresk dualitet mellem signifiant og signifié, ligesom der er flere gode grunde til at anlægge et kritisk syn på de semiotiske ideologier, der har præget den vestlige tænkning (Althusser 1975; Keane 2005:190-2.). Dette ligger da også som et værdifuldt element i den materielle og den ontologiske vendings bestræbelser.

\section{Søgeord: ontologi, candomblé, klassifikation, orden, manipulering, ritual}

\section{Litteratur}

Althusser, Louis

1975 Forelæsning: Basisbegreber og et eksempel. I: L- Althusser: Filosofi, ideologi og videnskab. En introduktion. Side 44-87. København: Bibliotek Rhodos.

Barber, Karin

1981 How Man Makes Gods in West Africa: Yoruba Attitudes towards "the Orisa". Africa: Journal of the International African Institute 51(3):724-45.

Bastide, Roger

1978 [1958] O Candomblé da Bahia. São Paulo: Companhia Editora Nacional/Mec.

Deleuze, Gilles \& Félix Guattari

2005 [1980] Tusind plateauer. Kapitalisme og skizofreni. København: Det Kongelige Danske Kunstakademis Billedkunstskole.

Durkheim, Émile \& Marcel Mauss

1963 [1903] Primitive Classification. Chicago: Chicago University Press.

Ellen, Roy

1988 Fetishism. Man 23(2):213-35.

Engelke, Mathew

2009 Reading and Time: Two Approaches to the Materiality of Scripture. Ethnos 74(2): 151-74. 
Frazer, James George

1996 [1922] The Golden Bough. A Study on Magic and Religion. London: Macmillan. Abridged Edition.

Gaonkar, Dipil Parameshwar \& Elizabeth A. Povinelli

2003 Technologies of Public Forms: Circulation, Transfiguration, Recognition. Public Culture 15(3):385-97.

Goldman, Marcio

1994 Razâo e Diferença. Afetividade, racionalidade e relativismo no pensamento de Lévy-Bruhl. Rio de Janiero: UFRJ Editora.

2007 How to Learn in an Afro-Brazilian Spirit Possession Religion. Ontology and Multiplicity in Candomblé. In: D. Berliner \& R. Sarró (eds.): Learning Religion. Anthropological Approaches. Pp. 103-17. New York \& Oxford: Berghahn Books. An Afro-Brazilian Theory of the Creative Process. An Essay in Anthropological Symmetrization. Social Analysis 53(2):108-29.

Henare, Amiria, Martin Holbraad \& Sari Wastell

2007 Introduction: Thinking Through Things. In: A. Henare, M. Holbraad \& S. Wastell (eds.): Thinking Through Things. Theorising Artefacts Ethnographically. Pp. 1-31. Abingdon: Routledge.

Heywood, Paolo

2012 Anthropology and What There Is. Reflections on "Ontology".

Cambridge Anthropology 30(1):143-51.

Holbraad, Martin

2007 Power and Powder: Multiplicity and Motion in the Divinatory Cosmology of Cuban Ifá (or Mana, again). In: A. Henare, M. Holbraad \& S. Wastell (eds.): Thinking Through Things. Theorising Artefacts Ethnographically. Pp. 189-225. Abingdon: Routledge.

2011 Can the Thing Speak? OAC Press, Working Papers Series 7:1-26.

Keane, Webb

1998 Calvin in the Tropics: Objects and Subjects in the Religious Frontier. In: P. Spyer (ed.): Border Fetishisms. Material Objects in Unstable Spaces. Pp. 13-35.

New York: Routledge.

2005 Signs Are Not the Garb of Meaning: On the Social Analysis of Material Things. In: D. Miller (ed.): Materiality. Pp. 182-205. Durham \& London: Duke University Press.

Latour, Bruno

2008 En ny sociologi for et nyt samfund. Introduktion til Aktør-Netværk-Teori.

København: Akademisk Forlag.

Lévy-Bruhl, Lucien

2010 [1923] Primitive Mentality. Boston: Beacon Press.

Manning, Paul \& Anne Meneley

2008 Material Objects in Cosmological Worlds: An Introduction. Ethnos 73(2):285-302.

May, Todd

2003 When Is a Deleuzian Becoming? Continental Philosophy Review 36:139-53.

Mol, Annemarie

2005 Ontological Politics. A Word and Some Questions. In: J. Law \& J. Hassard (eds.): Actor Network Theory and After. Oxford: Blackwell Publishing. 
Pietz, William

1985 The Problem of the Fetish, I. RES: Anthropology and Aesthetics 9:5-17.

1987 The Problem of the Fetish, II. RES: Anthropology and Aesthetics 13:23-45.

1988 The Problem of the Fetish, IIIa. RES: Anthropology and Aesthetics 16:105-23.

Salamon, Karen Lisa

$1990 \quad$ Skriften før tingene. Om skriften i jødisk tradition.

Tidsskriftet Antropologi 21/22:21-27.

Sjørslev, Inger

2006 On Leaving the Field. Closure and Continuity as Seen through the Lens of the Candomblé Axexé Ritual. Folk Journal of the Danish Ethnographic Society 46-47: 11-40.

2007 Ting og person. Bidrag til en socialitetsteknologi. I: I. Sjørslev (red.): Scener for samvær. Ritualer, performance og socialitet. Aarhus: Aarhus Universitetsforlag.

2012 The Material Subject as Political: Style and Pointing in Public Performance. Anthropological Theory 12(2):209-28.

Spyer, Patricia (ed.)

$1998 \quad$ Border Fetishisms. Material Objects in Unstable Spaces.

New York \& London: Routledge.

Venkatesan, Soumhya (ed.)

2010 Ontology is Just Another Word for Culture. Motion tabled at the 2008 meeting of the Group for Debates in Anthropological Theory, University of Manchester. Critique of Anthropology 30(2):152-200.

Viveiros de Castro, Eduardo

2003

AND. After-dinner speech at "Anthropology and Science", the 5th Decennial Conference of the Association of Social Anthropologists of Great Britain and Commonwealth, 14. juli. Manuscript (also published in Manchester Papers in Social Anthropology, 7). 